\title{
Intraoperative Cholangiography in Laparoscopic Cholecystectomy: Technique and Changing Indications
}

\author{
Laparoskopik Kolesistektomide Peroperatuvar Kolanjiyografi: Teknik ve Değișen \\ Endikasyonlar
}

Kamer Tomaoğlu

Esenyurt University Faculty of Health Sciences, İstanbul, Turkey

\begin{abstract}
Introduction: Although laparoscopic cholecystectomy (LC) is considered as the "gold standard" of cholecystectomy, the rate of bile duct injuries seems to be elevated when compared to open cholecystectomy. Intraoperative cholangiography (IOC) may prevent iatrogenic bile duct injuries or may diagnose missed bile duct injuries.
\end{abstract}

Methods: Between 1998 and 2016, 29 selective IOCs were performed in a total of $212 \mathrm{LCs}(13.7 \%)$. At the beginning of the study (1998-2002), the indications of IOC were past history of jaundice, elevation of cholestatic enzymes and dilation of the common bile duct or suspicion of common bile duct stones on abdominal ultrasound, whereas obscure biliary anatomy became the main intraoperative criteria during the following years.

Results: Of the 29 patients, 20 were female and 9 patients were male. The mean age was 54.4 years. IOC was successful in 26 cases (90\%). The median IOC time was 21.9 minutes. An anatomical variation was found in one patient. In this case, the cystic duct was opening into the right hepatic duct. The Wirsung duct was visualised in another patient, which was probably due to hyperpression of the sphincter of Oddi. No complication related to the procedure itself was encountered.

Conclusion: Although the routine use of IOC does not seem to be necessary, it may prevent bile duct injuries in selected cases. Surgeons should gain experience in performing the procedure, and the necessary equipment should be present in the operating room.

Keywords: Laparoscopic, cholecystectomy, intraoperative, cholangiography

\section{öz}

Amaç: Laparoskopik kolesistektomi (LK) günümüzde safra kesesi ameliyatlarında "altın standart" olarak kabul edilmiş olmakla birlikte, klasik kolesistektomi ile karşılaşııııldığında, iatrojenik safra yolu yaralanmalarında artışların meydana gelmiş olduğu görülmektedir. Laparoskopik peropratuvar kolanjiyografi (LPOK) uygulanması iatrojenik safra yolu yaralanmalarını önleyebilir ve gözden kaçmış olan bir yaralanmayı ortaya koyabilir.

Yöntemler: 1998-2016 yılları arasında LK yapılmış olan 212 olgudan 29 unda $(\% 13,7)$ selektif LPOK uygulandı. LPOK uygulama endikasyonları çalışmanın başlangıcında (19982002), geçirilmiş sarılık, kolestaz enzimlerinde yükselme ve preoperatif ultrasonografide koledokta taş şüphesi veya dilatasyon saptanması iken, sonraki yıllarda endikasyonumuz peroperatuvar anatomik yapılardan emin olamama olarak değiști.

Bulgular: LPOK uygulanan olguların 20'si kadın, 9'u erkekti. Yaş ortalaması 54,4 idi. Toplam 26 (\%90) hastada görüntülemede başarı sağlandı. Ortalama peroperatuvar kolanjiyografi süresi 21,9 dakika olarak ölçüldü. Bir hastada sistik kanalın sağ hepatik kanala açıldığı anatomik varyasyon görüntülendi. Bir hastada ise Wirsung kanalı görüntülendi ve bunun Oddi sfinkteri yüksek basıncına bağlı olduğu düşünüldü. Hiç̧ir hastada peroperatuvar kolanjiyografiye bağlı komplikasyon olmadı.

Sonuç: Genel kanı olarak, rutin LPOK kullanılması gerekli görülmemekle birlikte seçilmiş olgularda, iatrojenik safra yolu yaralanmalarını önleyebilir. Bu nedenle genel cerrahi uzmanlarının LPOK uygulanması konusunda tecrübe kazanmış olması ve gerekli altyapının ameliyathanede hazır bulunması gerekmektedir.

Anahtar Kelimeler: Laparoskopik, kolesistektomi, peroperatuar, kolanjiyografi 


\section{Introduction}

The rate of iatrogenic bile duct injuries seems to be more elevated in laparoscopic cholecystectomy (LC) than in open cholecystectomy $(1,2)$. The inflammatory process, adherence, intraoperative bleeding which may obscure good vision, common bile duct (CBD) tenting due to excessive traction, and anomalies of the biliary tract are all factors that are implicated in occurrence of iatrogenic bile duct injuries.

Biliary leakages or strictures may develop as a consequence of iatrogenic bile duct injuries necessitating several successive operations or endoscopic retrograde cholangiopancreatography (ERCP) procedures. Failure of these surgical or endoscopic procedures may give rise to increased morbidity and mortality rates $(3,4)$. Bile duct injuries may lead to several medico-legal problems as well $(1,3)$.

Routine or selective intraoperative cholangiography (IOC) may be an important tool to clearly delineate the biliary anatomy and to prevent an iatrogenic bile duct injury. On the other hand, IOC may diagnose a bile duct injury that has already occurred $(3,4)$. The indications of IOC have been reduced recently, largely due to technical improvements concerning radiologic examinations such as abdominal ultrasound, computed tomography (CT) scan, magnetic resonance cholangiopancreatography (MRCP) and diagnostic or therapeutic ERCP.

In the present study, the medical reports of patients who underwent IOC were retrospectively examined in order to evaluate the necessity and utility of IOC.

\section{Methods}

Ethical approval was waived in view of the retrospective nature of the study and all the procedures being performed were part of the routine care. Written and oral consent was obtained from the patients included in the study, and their data were evaluated within the scope of the study. The medical records of 212 patients who underwent LC between 1998 and 2016 in SP hospital were retrospectively examined. Of these, $29(13.7 \%)$ were submitted to IOC. The preoperative indications during the beginning period of the study (1998-2002) were history of jaundice, increase in cholestatsis enzymes and suspicion of CBD stones or dilation of $\mathrm{CBD}$ (>6 mm), whereas during the following years, the main indication became "obscure biliary tree anatomy" since preoperative radiologic examinations such as CT scan, MRCP and endoscopic procedures like ERCP eliminated other indications.

The age and gender of the patients, indications and the duration of IOC and results of cholangiograms were recorded. Patients were questioned regarding iodine allergy in preoperative period. Preoperative antibiotics were administered consisting of primary generation cephalosporins (Sefazol of $1 \mathrm{gr}$ ). The antibiotic course was not continued postoperatively.

\section{Technique of IOC}

The patient was installed in a supine position. Both arms were in abduction of $80^{\circ}$ while both legs were separated. The Surgeon was placed between the legs, and the assistant was situated on the left lateral side of the patient (French position).

LC was performed with four ports: The first port was umbilical with a diameter of $10 \mathrm{~mm}$. The second port of $5 \mathrm{~mm}$. diameter was introduced from the right lombar region on the anterior axillary line, between the anterior iliac spine and the point of the $12^{\text {th }}$ rib. A third port of 5 $\mathrm{mm}$. and a fouth one of $10 \mathrm{~mm}$ were placed in the subxyphoid and left hypochondrium respectively (Figure 1). A laparoscope of $30^{\circ}$ angle was used.

The dissection of Calot's triangle and identification of the cystic duct and cystic artery was followed by the application of a titanium clip proximally on the cystic duct, close to the infundibulum. Care was taken to keep a distance of at least $1.5 \mathrm{~cm}$ from the common bile duct. A small hemicirconferential incision was made just distal to the clip. A 15-gauge, 12-cm long "Cystic Duct Access Trocar Sheath Needle" (COOK Medical Inc. Bloomington, IL, USA) was introduced from the midline, on the line rejoining port no: 2 and no: 4 , on the midclavicular line (no: 5- Figure 1). A $4 \mathrm{~F}$ or $6 \mathrm{~F}$ urinary catheter was inserted into the peritoneal cavity via the needle depending on the thickness of the cystic duct. The infundibulum of the gallbladder was grasped, and right inferolateral traction was applied by grasper forceps introduced through port no: 2 . The catheter was grasped leaving a $2 \mathrm{~cm}$ free margin from its distal tip by another grasping forceps inserted through port no: 3 . The cystic duct was catheterized and loosely regrasped.

The permeability of the catheter was varified by flushing 2 or $3 \mathrm{~mL}$ of saline solution into the lumen. After making sure that it was water tight, the abdominal cavity was deflated.

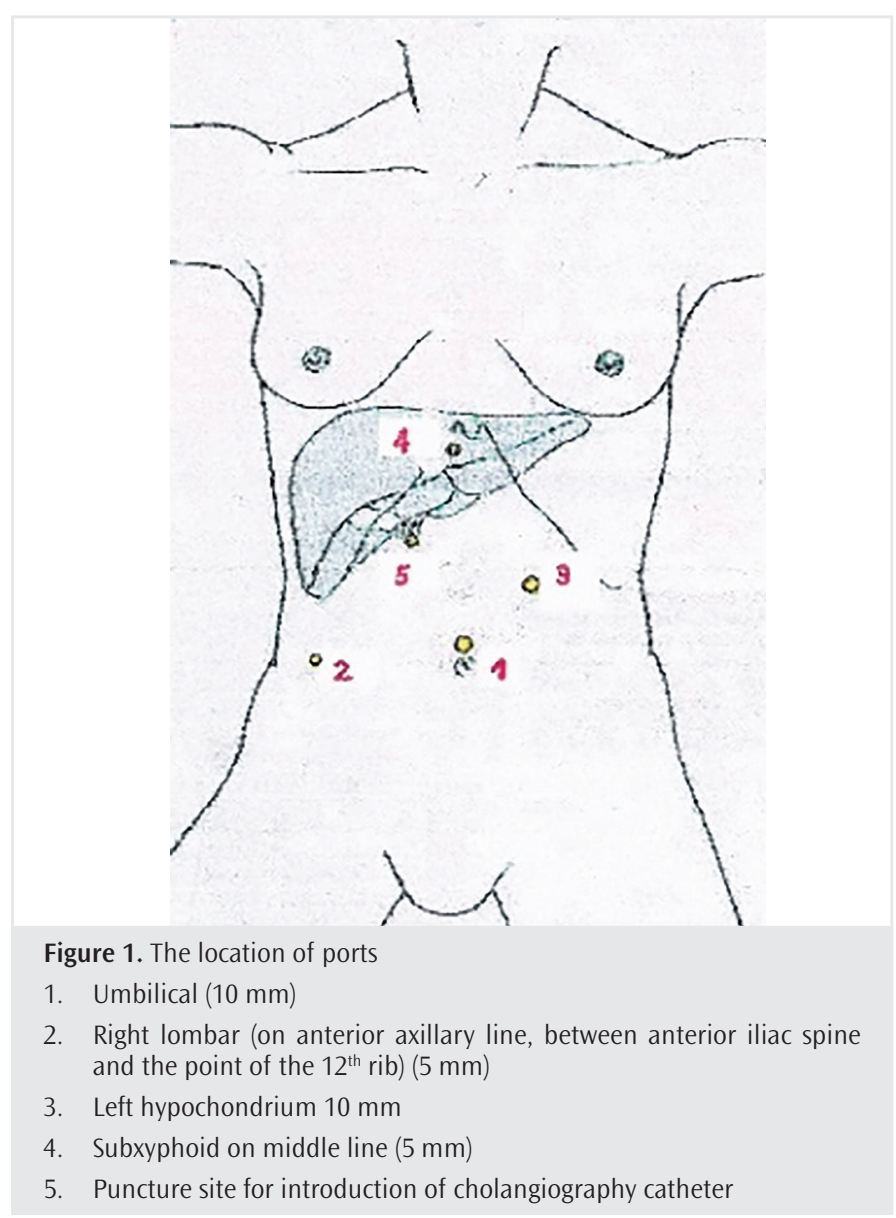


A C-arm radiological unit was focused on the right hypochondrium. 10 $\mathrm{mL}$ of contrast dye (10 $\mathrm{mL}$ of $1 / 3$ diluated Urografin) was administered into the catheter until the common bile duct was completely visualized. The passage of the contrast media into the duodenum was verified, and dynamic images were obtained. In order to visualize the proximal and intrahepatic bile ducts, an additional amount of contrast media of $10 \mathrm{~mL}$ was injected via the catheter, and the patient was placed in Trendelenburg position.

Consequently, cholangiogram images were printed (Figure 2).

Common bile duct and intrahepatic bile duct anatomy and diameter, the presence of lacunar calcula image, the passage of contrast media into the duodenum, the visibility of Wirsung duct and the presence of contrast media leakage were evaluated. The maneuver time was measured as the duration between the passing and the extraction of the catheter from the peritoneal cavity.

Peritoneal cavity was reinsufflated, and the catheter was extracted. Two additional titanium clips were placed distal to the cystic duct incision and the duct was sectioned.

The section of the cystic artery was performed after the IOC procedure in all cases.

\section{Statistical Analysis}

As statistical evaluation of continuous variables arithmetic mean \pm standard deviation and minimum-maximum values and for the discrete (qualitative) variables \% share ratios were presented as descriptive statistics.

\section{Results}

IOC was performed in 29 (13.7\%) out of 212 patients who underwent LC. Twenty patients were female, 9 patients were male. The mean age was $54.4 \pm 3.8$ years (minimum-maximum: $27-83$ ). IOC was successful in

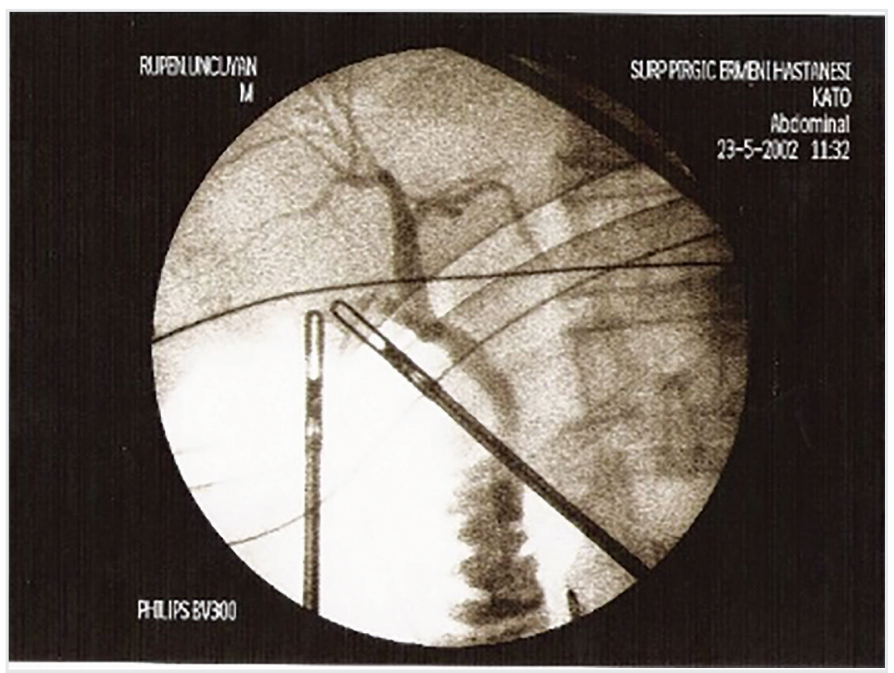

Figure 2. The position of instruments during IOC

1. Left grasper on Hartmann's pouch (port number 2)

2. Right grasper on distal end of cystic duct (port number 3)

IOC: Intraoperative cholangiography
$26(90 \%)$ patients in which the biliary anatomy was perfectly deliniated. In 3 patients, IOC was not possible due to impossible catheterization of the cystic duct.

The indications of IOC are presented in Table 1.

The median exploration time was $21.9 \pm 4.3$ minutes with a variable range between 15 and 40 minutes mostly due to cholangiogram interpretation.

In 26 patients where IOC was successful, the distance between the proximal clip and bile duct was greater than $1 \mathrm{~cm}$., the passage of contrast media into the duodenum was normal, and the bile duct anatomy was clearly identified. No lacunary images and no leakage of contrast media from the bile ducts was present.

In one patient, an anatomic variation was found where the cystic duct was opening into the right hepatic duct. In another patient, the Wirsung duct was visualized due to hyperpression of the sphincter of Oddi.

Symptomatic gall bladder stones were present in three unsuccessful cases.

No IOC related complications were observed. All patients except one were discharged the day after the operation.

In one patient, an increase in levels of direct bilirubin and cholestatic enzymes was observed. The IOC was considered normal in this patient. The elevated levels persisted until $5^{\text {th }}$ postoperative day. The patient was discharged on the $6^{\text {th }}$ day without any additional radiologic examinations. The follow-up examinations performed one month later showed no laboratory or radiologic abnormalities. No problem was encountered 3 years after the operation. No IOC was performed for intraoperative suspicion of bile duct injury.

\section{Discussion}

In the modern surgical era, the majority of cholecystectomies are performed laparoscopically, which is considered as "gold standard" of cholecystectomy. LC has several advantages such as improved cosmesis, reduced period of hospital stay and rapid convalescence, and no incidence of postoperative incisional hernias due to Kehr incision. The incidence of common bile duct injuries following LC, when compared to open cholecystectomy, has been shown to be more elevated as a side effect of this trend. Some studies have reported rates of iatrogenic bile duct injury between 0.2 to $1.1 \%(1,2,5)$.

The adherences and fibrosis which may be formed as a consequence of repeated cholecystitis attacks, past surgical operations, intraoperative

\section{Table 1. Indications of intraoperative cholangiography}

\begin{tabular}{|c|c|}
\hline Indication & Number of patients \\
\hline Increase in cholestasis enzymes & 10 \\
\hline History of jaundice & 3 \\
\hline $\begin{array}{l}\text { Suspicion of common bile duct stones } \\
\text { and preoperative ERCP }\end{array}$ & 2 \\
\hline Dilation of common bile duct ( $>6 \mathrm{~mm}$ ) & 5 \\
\hline Obscure biliary tree anatomy & 9 \\
\hline
\end{tabular}


bleeding which may obscure good vision, the tenting of common bile duct due to excessive traction, the experience of the surgeon are all factors that are accused in occurance of iatrogenic bile duct injuries $(5,6)$.

Bile duct injuries, whether diagnosed intraoperatively or postoperatively, are subject to several difficulties while exposing the patient to several invasive explorations such as repeated radiologic examinations, surgical interventions or endoscopic procedures like ERCP. ERCP is quite efficient in the management of ductal stones, and it has a morbidity rate of $7-11 \%$ and a mortality of $<1 \%$, especially if accompanied by endoscopic sphincterotomy (7). As a consequence, the life quality of the patient is lowered and morbidity and mortality rates are increased $(4,6)$.

IOC represents an important tool in diagnosing unsuspected CBD stones during $\mathrm{LC}$ performed either routinely or selectively. IOC may also deliniate the anatomy of the biliary tree, may prevent serious intraoperative complications and may decrease the morbidity and mortality rates (8).

At the beginning of laparoscopic experience, some authors have advocated routine use of IOC, which can detect significantly more biliary injuries as well as unexpected biliary anatomy of potential surgical relevance despite an increase in operative time and cost (9-13). On the other hand, false positive results may lead to unnecessary Common Bile Duct explorations or ERCP (11).

Stewart and Way (14) identified the two most important reasons for ductal injury during LC as: (a) false identification of CBD as the cystic duct and (b) aggressive efforts to stop bleeding. They outlined liberal use of IOC and cautious interpretation of the lack of opacification of the proximal CBD as a sign of its closure.

Wright and Wellwood (15) concluded that meticulous dissection of calots triangle is a more reliable safeguard against bile duct injuries than routine IOC. If the ductal anatomy is unclear, IOC or open conversion should be performed.

Collins et al. (16) concluded that treatment decision based on assessment by IOC alone would result in unnecessary intervention in $50 \%$ of patients who had either false positive studies or subsequently passed the stone, and one third of the patients with CBD stone at the time of cholecystectomy pass their stones spontaneously within 6 weeks of surgery.

Actually, many authors reserve IOC to selective cases when the biliary anatomy is not clearly defined intraoperatively or when iatrogenic bile duct injury is suspected. Variation in the biliary anatomy is common, and the incidence reported in the literature is around 10 to $28 \%(17,18)$. This has often been cited as a justification for the routine use of IOC to reduce the incidence of bile duct injury (19-21). However, review of the literature does not show any association between the occurance of anomalous anatomy and bile duct injuries (22).

Although the improvement of preoperative diagnostic tools has led to a decrease in indications of IOC, it still has to be performed in selected cases in patients with high and intermediate risk of CBD stones who have not had a preoperative MRCP if ductal anatomy is unclear during LC $(6,8)$.

In another study, methylene blue was injected in the gallbladder in order to visualize the anatomy of the biliary tree. It was stated that a decreased rate of iatrogenic bile duct injury was obtained by this technique. The leakage of methylene blue was easily demonstrated, and the staining of the duodenum indiretly proved the presence of intact common bile duct (23).

The success rates are given between 60 to $90 \%$, and unsuccessful procedures are mostly due to the presence of very thin cystic ducts $(8,24)$. Our results, with a success rate of $90 \%$, are in correlation with these studies.

We performed IOC with wider indications at the beginning of our experience, but during the following years, the indications were mostly limited to intraoperative suspicion of obscure biliary anatomy. We think that this was largely due to technical improvement of radiologic examinations such as CT scan, MRCP and endoscopic examinations like ERCP.

The average IOC time is given as 20 minutes which is in accordance with our results (25). We found an average IOC time as 21.9 minutes. The average time for performing IOC was progressively shortened, while the experience was accumulated. Despite the limited number of cases included in the present study, we may conclude that especially at the beginning of the experience concerning LC, an average additional time of 21.9 minutes facilitated the identification of cystic duct and common bile duct and a bile duct injury was possibly prevented. In one case where the cystic duct was opening to the right hepatic duct, the performance of IOC avoided an injury to the right hepatic duct.

No additional intraoperative technical difficulty was encountered in patients who presented with acute cholecystitis in patients with a history of acute edematous pancreatitis or in patients who underwent preoperative ERCP procedure. No intraoperative or postoperative complications were encountered due to the procedure itself.

\section{Conclusion}

In current practice, although the routine use of IOC is not recommended, it is crucial for every surgeon performing LC to be able to perform the IOC technique and to interpret the dynamic cholangiography and/ or cholangiograms. The necessary radiologic equipmemt (C-arm X-ray device) should always be available in the OR.

\section{Ethics}

Ethics Committee Approval: Ethical approval was waived in view of the retrospective nature of the study and all the procedures being performed were part of the routine care.

Informed Consent: Written and oral consent was obtained from the patients

Peer-review: Externally and internally peer-reviewed.

Financial Disclosure: The author declared that this study received no financial support.

\section{References}

1. Dolan JP, Diggs BS, Sheppard BC, Hunter JG. Ten-year trend in the national volume of bile duct injuries requiring operative repair. Surg Endosc 2005; 19: $967-73$. 
2. Waage A, Nilsson M. latrogenic bile duct injury: a population-based study of 152776 cholecystectomies in the Swedish Inpatient Registry. Arch Surg 2006; 141: 1207-13.

3. Kapoor VK. Medico-legal aspects of bile duct injury. J Minim Access Surg 2016; 12: $1-3$.

4. Törnqvist B, Strömberg C, Akre O, Enochsson L, Nilsson M. Selective intraoperative cholangiography and risk of bile duct injury during cholecystectomy. Br J Surg 2015; 102: 952-8.

5. Melton GB, Lillemoe KD, Cameron JL, Sauter PA, Coleman J, Yeo CJ. Major bile duct injuriesassociated with laparoscopic cholecystectomy: effect of surgical repair on quality of life. Ann Surg 2002; 255: 888-95.

6. Jenny MLR, Agneta KM. Quality-of-life after bile duct injury: intraoperative detection is crucial. A national case-control study. HPB (Oxford) 2016; 18: 1010-6.

7. Phillips EH. Routine versus selective intraoperative cholangiography. Am J Surg 1993; 165: 505-7.

8. Philips EH, Berci G, Carroll B, Daykhovsky L, Sackier J, Paz-Partlow M. The Importance of Intraoperative cholangiography during laparoscopic cholecystectomy. Am Surg 1990; 56: 792-5.

9. Photi ES, El-Hadi A, Brown S, Swafe L, Ashford-Wilson S, Barwell J, et al. The Routine Use of Cholangiography for Laparoscopic Cholecystectomy in the Modern Era. JSLS 2017; 21: e2017.00032.

10. Flowers JL, Zucker KA, Graham SM, Scovill WA, Imbembo AL, Bailey RW. Laparoscopic cholangiography. Results and indications. Ann Surg 1992; 215: 209-16.

11. Borjeson J, Liu SK, Jones S, Matolo NM. Selective intraoperative cholangiography during laparoscopic cholecystectomy: how selective? Am Surg 2000; 66: 616-815.

12. Flum DR, Dellinger EP, Cheadle A, Chan L, Koepsell T. Intraoperative cholangiography and risk of common bile duct injury during cholecystectomy. JAMA 2003; 289: 1639-44.

13. Fletcher DR, Hobbs MS, Tan P, Valinsky LJ, Hockey RL, Pikora TJ, et al. Complications of cholecystectomy: risks of the laparoscopic approach and protective effects of operative cholangiography: a population based study. Ann Surg 1999; 229: 449-57.

14. Stewart L, Way LW. Bile duct injuries during laparoscopic cholecystectomy. Factors that influence the results of treatment. Arch Surg 1995; 130: 1123-8.

15. Wright KD, Wellwood JM. Bile duct injury during laparoscopic cholecystectomy without operative cholangiogram. Br J Surg 1998; 85: 191-4.

16. Collins C, Maguire D, Ireland A, Fitzgerald E, O'Sullivan GC. A prospective study of common bile duct calculi in patients undergoing laparoscopic cholecystectomy: natural history of choledocholithiasis revisited. Ann Surg 2004; 239: 28-33.

17. Goor DA, Ebert PA. Anomalies of the biliary tree. Arch Surg 1972; 104: 302-9.

18. Hamlin JA. Biliary duct anomalies. In: Berci G, Hamlin JA, editors. Operative biliary radiology. Baltimore: Williams \& Wilkins; 1981.p.109-35.

19. Walters W, Philips SK. The increasing frequency of injury of the common bile duct, hepatic duct. Surgery 1949; 25: 469-75.

20. Foster JH, Wayson EE. Surgical significance of aberrant bile ducts. Am J Surg 1962; 104: 14-20

21. Moosman DA, Coller FA. Prevention of traumatic injury to the bile ducts. Am J Surg 1951; 82: 132-7.

22. Metcalfe MS, Ong Thao, Bruening Martin H, Iswariah Harish, Wemyss Holden Simon A, Maddern Guy J. Is laparoscopic intraoperative cholangiogram a matter of routine? Am J Surg 2004; 187: 475-81.

23. Sarı YS, Tunalı V, Tomaoglu K, Karagöz B, Güney A, Karagöz. Can bile duct injuries be prevented? "A new technique in laparoscopic cholecystectomy". BMC Surg 2005; 5: 14.

24. Berci G, Sackier J, Paz-Partlow M. Routine or selective intraoperative cholangiography during laparoscopic cholecystectomy. Am J Surg 1991: 161: 355-60.

25. Nathanson LK, Shimi S, Cuschieri A. Laparoscopic cholecystectomy: The Dundee technique. Br J Surg 1991; 78: 155-9. 